\title{
EVALUATION OF KNOWLEDGE TRANSFER INTERNATIONALISATION LEVEL
}

\author{
Rasa Misiūnaitė ${ }^{1}$, Eigirdas Žemaitis² \\ Department of Business Technologies and Entrepreneurship, Faculty of Business Management, \\ Vilnius Gediminas Technical University, Sauletekio av. 11, LT-10223 Vilnius, Lithuania \\ E-mails: ${ }^{1}$ rasa.misiunaite@stud.vgtu.lt (corresponding author); ${ }^{2}$ eigirdas.zemaitis@vgtu.lt
}

Received 29 March 2020; accepted 04 April 2020

\begin{abstract}
Knowledge and the ability to transfer it effectively becomes a valuable skill, that goes beyond a particular business sector. In 2015 United Nations developed the 2030 Agenda for Sustainable Development Goals (SDG), which emphasize global partnership and collaboration as some of the key criteria in order to achieve tangible results. Authors raise the hypothesis about a set of national level criteria, which help to forecast the level of European Union countries contribution to SDG. Research aims to evaluate EU countries' potential to contribute to $17 \mathrm{SDG}$, by measuring the level of international knowledge transfer. Authors analyze scientific approaches to knowledge transfer, its measurement, match selected measurement aspects with corresponding data from Global Competitiveness Index and rank EU countries by using TOPSIS multi-criteria decision making method.
\end{abstract}

Keywords: knowledge, knowledge transfer, internationalization, ranking, sustainable development goals.

JEL Classification: M16, M14,O190.

\section{Introduction}

Rapid internationalization is causing transformations in business, public and other sectors in multiple ways. It challenges to look for new sustainable competitive advantages (Sheng et al., 2013), that would remain valid despite the geographical boundaries. One of the resources that become critical in a global landscape is knowledge (Patriotta, Castellano, \& Wright, 2013) and its effective transfer. Knowledge and its transfer play a vital role in building a company's differentiation, increasing efficiency, creating a long-term business strategy (Tangaraja et al., 2016).

While knowledge and its transfer are the object of increasing importance in business and science, it is often analysed from the perspective of a particular company, business sector or organization (Raudeliuniene \& Szarucki, 2019). Nowadays context suggests, knowledge transfer can be perceived from a broader, country level perspective. In order to bring knowledge transfer not only to a broader, but at the same time new perspective, it is linked with Sustainable Development Goals, which is a topic of increasing presence in a scientific context (Hogan et al., 2018; Galli et al., 2018; Fritz et al., 2019; Xiao et al., 2018; Zimm, Sperling, \& Busch, 2018 if to mention only few).

The Agenda for Sustainable Development Goals was developed by United Nations in 2015 as a plan of actions in areas "of critical importance for humanity and the planet": people, planet, prosperity, peace and partnership (according to Sustainable Development Goals knowledge platform). SDGs strategy highlights collaboration and global partnership as key criteria in achieving 17 goals. Knowledge and its transfer are in the very nature of partnership and collaboration, so naturally, it might affect countries' contribution to SDG.

Authors raise the hypothesis: there is a set of particular national level criteria which help to forecast and track the level of European Union countries contribution to SDG. This research aims to evaluate EU countries' potential contribute to 17 SDG, by measuring their level of international knowledge transfer.

By examining this hypothesis, study aims to evaluate EU countries' potential to contribute to 17 SDG. Especially Goal 9 and Goal 17 which are the following:

- Goal 9: "Build resilient infrastructure, promote inclusive and sustainable industrialization and foster innovation", by focusing on "quality, reliable, sustainable and resilient infrastructure", promoting inclusive and sustainable industrialization, enhancing scientific research, upgrading technological capabilities, increasing access to information and communications technology;

- Goal 17: "Strengthen the means of implementation and revitalize the global 
partnership for sustainable development", by focusing on finance, technology, capacity-building, trade and systemic-issues.

The research object is a national level of international knowledge transfer among EU countries. The purpose of the study is to rank European Union countries by their potential to transfer knowledge internationally. Tasks set for achieving the goal:

1. To investigate scientific literature and identify different approaches to main stages, attributes, and types of measurement of international knowledge transfer;

2. To match identified measurement types with corresponding data from Global Competitiveness Index;

3. To rank European Union countries by previously selected criteria.

In this research multi-criteria decision making method, TOPSIS (Technique of order preference by similarity to ideal solution) is used. This study will contribute to existing theoretical knowledge in the knowledge transfer field. It can be used as one of the tools for EU countries to run a regular review of their performance while reaching SDGs until 2030.

The research is based only on selected scientific articles and publicly available primary data. This research does not involve external experts and relies on the authors' expertise.

\section{Theoretical framework of knowledge transfer}

Knowledge management, which consist of multiple stages, is a discipline emerging in scientific landscape (Raudeliūnienè, Davidavičienè, \& Jakubavičius, 2018). Knowledge transfer, as a one of the knowledge management stages, is a term broadly and differently described by various authors and is one of the usually studied knowledge management processes (Raudeliuniene \& Szarucki, 2019).

This study aims to identify and compare different scientific approaches to main stages, common attributes and elements of knowledge transfer. Theoretical analysis is continued with different scientific approaches to the measurement of knowledge transfer.

The most generalized way to approach knowledge transfer is the transmission of messages or information from the source (interchangeably identified as a "sender", "supplier") to the recipient (interchangeably called "receiver", "user") (Szulanski, Cappetta, \& Jensen, 2004). However, even though knowledge transfer is a common research object, there is quite some confusion in the knowledge management literature (Tangaraja et al., 2016). Knowledge transfer is sometimes labelled differently, and scientists should pay attention not to use the terms "knowledge transfer" and "knowledge sharing" interchangeably in order to avoid confusion. Tangaraja et al. (2016) explores differences between knowledge transfer and knowledge sharing (see Table 1) and identifies knowledge transfer as a more complex process that occurs in multiple levels (individual, group, product line, etc.).

Table 1. Differences between knowledge sharing and knowledge transfer. Based on Tangaraja et al. (2016)

\begin{tabular}{|l|l|}
\hline \multicolumn{1}{|c|}{ Concept } & \multicolumn{1}{c|}{ Characteristics } \\
\hline $\begin{array}{l}\text { Knowledge } \\
\text { sharing (KS) }\end{array}$ & $\begin{array}{l}\text { Is a critical stage in KT (using per- } \\
\text { sonalized strategy). Occurs at an indi- } \\
\text { vidual level (unidirectional sharing). } \\
\text { People-to-people process. }\end{array}$ \\
\hline $\begin{array}{l}\text { Knowledge } \\
\text { transfer } \\
(\mathrm{KT})\end{array}$ & $\begin{array}{l}\text { Involves great participation of source } \\
\text { (sender who shares the knowledge) } \\
\text { (using personalization strategy). Can } \\
\text { occur at an individual level, as well as } \\
\text { higher levels, such as group, product } \\
\text { line, department or division and or- } \\
\text { ganization. More complex than KS. }\end{array}$ \\
\hline
\end{tabular}

This study further focuses only on knowledge transfer, covering both tacit and explicit types of knowledge. Knowledge transfer, despite the core idea of information or message transition to another unit, is described differently by different authors and highlights different aspects of KT (Table 2).

At the very end of the XX century, KT was described as an "exchange" of knowledge (Nobeoka, 1995; Naboeka \& Cusumano, 1997). The word itself suggests KT was perceived as a twoway process, where each participating party both send and receive knowledge. With time KT definition changed, role of receiving party as well: from previously suggested idea of double role of each party, receiver later or is perceived only as a recipient of transferred knowledge, without the need to transfer some information in return (Szulanski et al., 2004; Joshi et al., 2007). Recent scientific sources suggest KT is a "process" (Bagheri et al., 2015) that consists of continuous interactions between actors.

The role of knowledge transfer is changing, it is becoming a more integrated, seamless and natural process in different sectors. Knowledge transfer is changing from "on-off" to "always-on" process. The process of knowledge transfer consists of a set of actions (or "stages"). 
Table 2. Knowledge transfer definitions

\begin{tabular}{|c|c|c|}
\hline Author & Year & Definition \\
\hline $\begin{array}{l}\text { Nobeoka; } \\
\text { Nobeoka } \\
\text { and } \\
\text { Cusumano }\end{array}$ & $\begin{array}{l}1995 ; \\
1997\end{array}$ & $\begin{array}{l}\text { Exchange of knowledge } \\
\text { through simultaneous and in- } \\
\text { tegrated management. }\end{array}$ \\
\hline Argote & 1999 & $\begin{array}{l}\text { The process by which } \\
\text { knowledge is deliberately } \\
\text { moved across organizational } \\
\text { boundaries to increase or lev- } \\
\text { erage a firm's knowledge base. }\end{array}$ \\
\hline Szulanski & 2003 & $\begin{array}{l}\text { A dyadic (direct) exchange } \\
\text { between a source and a receiv- } \\
\text { ing unit involved in a transfer } \\
\text { event. }\end{array}$ \\
\hline $\begin{array}{l}\text { Szulanski } \\
\text { et al. }\end{array}$ & 2004 & $\begin{array}{l}\text { Transmission of a message } \\
\text { from a source to the recipient } \\
\text { in a given context. }\end{array}$ \\
\hline $\begin{array}{l}\text { Joshi, S. } \\
\text { Sarker, and } \\
\text { S. Sarker }\end{array}$ & 2007 & $\begin{array}{l}\text { Activities of exchanging ex- } \\
\text { plicit or tacit knowledge be- } \\
\text { tween two agents, during } \\
\text { which one agent receives and } \\
\text { applies the knowledge provid- } \\
\text { ed by the other agent. }\end{array}$ \\
\hline $\begin{array}{l}\text { Peng, Dey, } \\
\text { and Lahiri }\end{array}$ & 2014 & $\begin{array}{l}\text { The process through which the } \\
\text { knowledge state of one actor is } \\
\text { affected by that of another and } \\
\text { the outcome is, knowledge is } \\
\text { passed from the source to the } \\
\text { destination. }\end{array}$ \\
\hline $\begin{array}{l}\text { Bagheri, } \\
\text { Kusters, and } \\
\text { Trienekens }\end{array}$ & 2015 & $\begin{array}{l}\text { The process by which actors } \\
\text { share knowledge among them- } \\
\text { selves through ongoing inter- } \\
\text { actions. }\end{array}$ \\
\hline
\end{tabular}

The exact set of these actions is often combined into a model, which varies by scientists and their interpretations, context or a sector. Frank and Duarte Ribeiro (2014) conduct an analysis to compare 14 knowledge transfer models. The authors classified models into 5 phases. Models of this study, in addition to classical approaches to knowledge transfer, systematized in Appendix 1.

This significant analysis of Frank and Duarte Ribeiro (2014) proves there are multiple approaches to knowledge transfer stages. However, there are few commonly identified stages of KT: knowledge awareness and acquisition, communication or transfer, knowledge application. Each stage has a unique function and can be affected by different internal and external factors. In addition, each stage can be measured in different ways. However, measurement is perceived as one of the most complicated knowledge management activities due to its intangible nature (Chen et al., 2009 in Ragab and Arisha, 2013).
Authors discuss knowledge measurement and often relate knowledge measurement with another concept - Intellectual Capital (Galbraith, 1969 in Ragab and Arisha, 2013). This term is described as a "knowledge, information, intellectual property, and experience that can be put to use to create wealth" (Ragab and Arisha, 2013). This perspective to knowledge measurement suggests a wider spectrum of approaches to its measurement. Ragab and Arisha (2013) present two organizational points of views to Intellectual Capital measurement:

1. Internal: this perspective described as efforts to identify not yet realized knowledge assets inside the company, so that they could be utiliszd more effectively.

2. External: his perspective reflects the view that a company's value consists of both tangible and intangible assets, inspired by the gap between company's book and market values. The authors identify three main approaches to measure Intellectual Capital while taking into account tangible and intangible assets: 1) Financial methods, IC methods and Performance methods.

Wong et al. (2015) analyze tools and techniques to knowledge management within two decades. Authors structured theoretical knowledge into eight knowledge management performance measurement tools and four techniques presented in Appendix 2.

Wong et al. (2015) analysis shows the broad scope of ways to approach and measure knowledge management performance. However, despite the scientific evidence of knowledge management performance is being a difficult object to measure, knowledge transfer is not anyhow easier. Knowledge transfer is a complex object to measure and there are no specific ways to do it, according to Nor Aziati, Juhana, and Nor Hazana (2014). Authors identify that scholars tend to measure knowledge transfer by the outcome of its process or the input to the process (for example, dedicated budget, investment, etc.), but ignores the complexity of the process. Authors classified three approaches to knowledge transfer measurement:

1. Changes at the recipient side: changes in the performance of recipient, changes in an existing knowledge base of the recipient, changes in knowledge that is collective.

2. Outcome and process dimensions: outcome dimension analyses KT from both 
financial (project cost reduction, stakeholder's equity, number of patents, intellectual property) and non-financial (amount of successful knowledge transfer engagements during a particular period of time, change in level of learning-by-doing knowledge, frequency of contact with the source of knowledge) point of view.

3. Learning performance or learning capabilities perspective: extent, speed, type and nature of knowledge that is perceived as "learned".

Authors based their study on collected insights on knowledge management performance measurement and approaches on how to measure knowledge transfer and adapt it to the measurement of international knowledge transfer level in EU.

\section{Research methodology}

Authors implement this study in four stages:

1. Scientific literature analysis;

2. Collection of insights regarding knowledge transfer measurement;

3. Identification of key areas for data accumulation for each EU country;

4. Ranking of EU countries by using gathered data and multi-criteria decision making methodology.

Stages 1 and 2 are covered in the first chapter led to Stage 3 and identification of three main areas for further research and data collection:

1. Knowledge transfer input: activities meant to improve, empower and motivate knowledge transfer;

2. Knowledge transfer outcome: result caused by knowledge transfer and transferred knowledge application.

3. Learning performance/capabilities: level of various skillsets, which might cause higher knowledge of individuals and their willingness to transfer it.

Identified areas are used for further analysis and matched with representing data from the Global Competitiveness Index (GCI), 2018 (Global Competitiveness Report). This particular index is chosen over a few other considered options like "Global Innovation Index", "World Happiness Report" and "Global Knowledge Index" due to its complexity and broad information scope. In addition, other considered indexes represented information, that overlaps with the one presented in GCI.

GCI is a global survey organized and conducted by the World Economic Forum. It identifies key drivers of the long-term competitiveness of countries and works as an "economic compass" meant to help leaders to navigate in the light of the fourth industrial revolution. The index combines well-established criteria with the new ones that empower productivity and growth. In total 135 countries are analyzed through twelve aspects: institutions; infrastructure; ICT adoption; macroeconomic stability; health; skills; product market; labor market; financial system; market size; business dynamism; and innovation capability. These aspects all together combine 98 indicators, derived from two sources: World Economic Forum's Executive Opinion Survey and data from multiple international organizations.

The authors matched previously identified knowledge transfer measurement types with the reflective criteria from the GCI (see Table 3). These criteria are matched with appropriate data for all European Union countries.

Table 3. Type of knowledge transfer measurement and criteria that reflects it at the GCI

\begin{tabular}{|l|l|}
\hline $\begin{array}{c}\text { Aspect of } \\
\text { knowledge transfer } \\
\text { internationalization } \\
\text { measurement }\end{array}$ & \multicolumn{1}{c|}{$\begin{array}{c}\text { Criteria that reflects } \\
\text { measurement type }\end{array}$} \\
\hline \multirow{4}{*}{$\begin{array}{l}\text { Knowledge transfer } \\
\text { outcome }\end{array}$} & $\begin{array}{l}\text { Future orientation of } \\
\text { government (1-7 (best) rank) }\end{array}$ \\
\cline { 2 - 2 } Knowledge transfer & $\begin{array}{l}\text { International co-inventions } \\
\text { (applications/million pop.) }\end{array}$ \\
\cline { 2 - 2 } input & $\begin{array}{l}\text { State of cluster development } \\
\text { (1-7 (best) rank) }\end{array}$ \\
\cline { 2 - 2 } (1-7 (best) rank)
\end{tabular}

In Stage 4 authors used multi-criteria decision making methodology to use gathered data for EU countries ranking by the level of international knowledge transfer. Knowledge transfer is a question of multi-criteria nature itself since it is influenced by multiple internal and external aspects. This suggests a multi-criteria decision making method should be used. This study is based on 
TOPSIS method (Technique of order preference by similarity to ideal solution) and analyzes quantitative factors.

TOPSIS methodology, invented by developed by Hwang and Yoon (1981), and is commonly used for problems, that involve multiple criteria in decision making (Hanine et al., 2016). This method compares a given set of alternatives by their geometric distance between each alternative and ideal alternative as well as a negative alternative. The ideal alternative is the one that has the highest level of all considered attributes and negative alternative - the lowest values of attributes. TOPSIS method helps to identify the best alternative - with the smallest geometrical distance to ideal alternative and the longest distance to the negative alternative. TOPSIS method consists of six steps.

Step 1: calculation of normalized ratings by using Euclidean normalization:

$x_{\text {norm }}=x / \sqrt{\Sigma x^{2}}$,

where: $x$ - primary value; $x_{\text {norm }}$ - normalized value.

Step 2: calculation of weighted normalized ratings:

$v_{i j}=w_{j} \times r_{i j} ; i=1,2, \ldots, m$; and $j=1,2, \ldots, n$,

where: $v_{i j}$-weighted normalised rating; $w_{j}$ - weight of criteria, $r_{i j}$ - primary value.

Step 3: identification of positive-ideal and negative-ideal solutions:

$a^{*}=\left\{v_{1}^{*}, v_{2}^{*}, \ldots, v_{j}^{*}, \ldots, v_{n}^{*}\right\}=$

$\left\{\left(\max _{i} v_{i j} \mid j \in J_{1}\right),\left(\min _{i} v_{i j} \mid j \in J_{2}\right) \mid i=1, \ldots, m\right\}$,

$a^{-}=\left\{v_{1}^{-}, v_{2}^{-}, \ldots, v_{j}^{-}, \ldots, v_{n}^{-}\right\}=$

$\left\{\left(\max _{i} v_{i j} \mid j \in J_{1}\right),\left(\min _{i} v_{i j} \mid j \in J_{2}\right) \mid i=1, \ldots, m\right\}$,

where: $a^{*}$-positive-ideal solution; $a^{-}$- positivenegative solution.

Step 4: calculation of Euclidean distance (separation) of each alternative from the ideal solutions are measured:

$$
\begin{aligned}
& S_{i}^{*}=\sqrt{\sum_{j}\left(v_{i j}-v_{j}^{*}\right)^{2}}, \\
& S_{i}^{-}=\sqrt{\sum_{j}\left(v_{i j}-v_{j}^{-}\right)^{2}},
\end{aligned}
$$

where: $S_{i}^{-}$- distance to positive-negative solution; $S_{i}^{*}$ - distance to positive-ideal solution.

Step 5: calculation of similarities to positiveideal solution:

$C_{i}^{*}=S_{i}^{-} /\left(S_{i}^{*}+S_{i}^{-}\right)$,

Step 6: rank of preference order, all alternatives are being ranked from best to worst or vice versa.

The authors choose TOPSIS as the best method to achieve the aim of this study - to rank EU countries by the level of knowledge transfer internationalization. Since the issue itself is multicriteria by its very nature, this type of method will help to take into account important aspects, influencing knowledge transfer internationalization.

\section{Research results}

Calculations were done according to the steps presented in the methodology part, Stage 4. Values gathered from GCI regarding each country were normalized, weighted by weights given for each criterion by experts - authors of article. Weights are presented in Table 4.

Table 4. Criteria weights

\begin{tabular}{|l|c|}
\hline \multicolumn{1}{|c|}{ Selected criteria } & Weight \\
\hline Future orientation of government & 0.09 \\
\hline International co-inventions & 0.12 \\
\hline State of cluster development & 0.11 \\
\hline Quality of vocational training & 0.08 \\
\hline Intellectual property protection & 0.09 \\
\hline Internet users & 0.13 \\
\hline Skill set of graduates & 0.09 \\
\hline Digital skills among population & 0.19 \\
\hline Multi-stakeholder collaboration & 0.1 \\
\hline
\end{tabular}

All calculations lead to the result - rank, which reflects level of knowledge transfer internationalization in 28 European Union countries (Table 5).

Results indicate that TOP5 countries with the most established environment for international knowledge transfer are as follows:

- Luxembourg;

- Sweden;

- Austria;

- Denmark;

- Finland. 
Table 5. Knowledge transfer internationalization level by the country

\begin{tabular}{|c|c|c|}
\hline Rank & Country & Calculated value \\
\hline 1 & Luxembourg & 0.91671 \\
\hline 2 & Sweden & 0.73697 \\
\hline 3 & Austria & 0,66987 \\
\hline 4 & Denmark & 0.64515 \\
\hline 5 & Finland & 0.64466 \\
\hline 6 & Belgium & 0.56934 \\
\hline 7 & Netherlands & 0.55938 \\
\hline 8 & Germany & 0.54742 \\
\hline 9 & Ireland & 0.49601 \\
\hline 10 & United Kingdom & 0.48758 \\
\hline 11 & Estonia & 0.38862 \\
\hline 12 & France & 0.35497 \\
\hline 13 & Malta & 0.30899 \\
\hline 14 & Czechia & 0.29413 \\
\hline 15 & Latvia & 0.26257 \\
\hline 16 & Spain & 0.26230 \\
\hline 17 & Slovakia & 0,26128 \\
\hline 18 & Cyprus & 0.24978 \\
\hline 19 & Slovenia & 0.23836 \\
\hline 20 & Hungary & 0.22989 \\
\hline 21 & Lithuania & 0,22866 \\
\hline 22 & Portugal & 0.22294 \\
\hline 23 & Italy & 0.20153 \\
\hline 24 & Poland & 0.18516 \\
\hline 25 & Croatia & 0.14842 \\
\hline 26 & Romania & 0.13864 \\
\hline 27 & Bulgaria & 0.12852 \\
\hline 28 & Greece & 0.12340 \\
\hline
\end{tabular}

These countries stood out in a GCI by the number of internet users, level of intellectual property protection, level of digital skills, and level of the skill set of graduates. This suggests TOP5 countries in the ranking have established and effective education system, there is also a significant level of digital literacy, which indicates the future orientation of these countries and their readiness to face internationalization challenges.

Luxembourg, Sweden, Austria, Denmark and Finland could potentially provide a higher contribution in reaching SDGs by 2030, especially Goal 9 "Build resilient infrastructure, promote inclusive and sustainable industrialization and foster innovation" and Goal 17 "Strengthen the means of implementation and revitalize the global partnership for sustainable development". Tangible international contribution to SDGs is beneficial for both receivers of created benefits and its suppliers, since the life of receivers will be improved, and the in- ternational reputation of suppliers will be increased.

Countries with the highest knowledge transfer internationalization level take high positions in GCI as well: Luxembourg - 19th place, Sweden 9th place, Austria - 22nd place, Denmark - 10th place and Finland - 11th place out of 140 countries. Such similarities in both rankings suggest these 5 countries have a more established financial system, pay attention to education and actual skills of the population, are focused on business dynamism and innovation capability are more prepared for international knowledge transfer.

The ranking also identifies countries with the least established international knowledge environment. These countries are as follows:

$$
\begin{aligned}
& \text { - Poland; } \\
& \text { - Croatia; } \\
& \text { - Romania; } \\
& \text { - Bulgaria; } \\
& \text { - Greece. }
\end{aligned}
$$

Countries that appear at the last five positions in the ranking have a significantly lower level of international co-invention, low amount of internet users, a low state of cluster development and low future orientation of government. Result suggests, these countries pay not enough attention to international collaboration and in general, are not enough oriented into changing the needs of business environment and lacks behind in an international landscape.

According to this rank and its potential relationship with the achievement of SDGs in 2030, Poland, Croatia, Romania, Bulgaria and Greece at this moment provides lower contribution. This result suggests a low interest in international collaboration and "global partnership" as key elements in reaching SDGs.

These particular countries are also ranked lower in GCI compared with other EU countries: Poland -37 th place, Croatia - 68th place, Romania - 52nd place, Bulgaria - 51st place and Greece 57 th place out of 140 countries. Even though these five countries are ranked in the first part of the GDI, they take place some of the lowest positions among EU countries.

The rank highlights countries with the highest and the lowest level of internationalization of knowledge transfer. At the same time, it emphasizes countries' future orientation and level of attention paid to the challenges of the modern business landscape. The ranking proves the hypothesis of the study: European Union countries with a higher focus on national factors like infrastructure, education, business intelligence and others, develop a 
higher level of international knowledge transfer and can deliver tangible contribution in achieving SDGs by 2030.

\section{Conclusions}

The authors investigated scientific literature and identified different approaches to knowledge transfer. The very essence of knowledge transfer was analyzed as well as the transformation of its definition within a time. Classical approaches to knowledge transfer highlight the idea of the "exchange" of information, meaning knowledge supplier is at the same time a receiver of knowledge provided by another actor. Modern approaches suggest knowledge transfer is rather an "ongoing process", with no clear start and end. Authors collected insights regarding the internationalization of knowledge transfer measurement and focused on classical approaches which highlight the importance of outcomes (what tangible value was created) and inputs on international knowledge transfer (training, tools, etc.) as well as learning performance.

Authors matched insights regarding the measurement of internationalization knowledge transfer with particular criteria and values reflecting them on the national level of each country of EU. Data was taken from the Global Competitiveness Index 2018. Nine criteria were chosen: three that represent knowledge transfer outcome (future orientation of government, international co-invention, state of cluster development), two that represent knowledge transfer input (quality of vocational training and intellectual property protection) and four criteria that indicates learning performance (internet users, the skill set of graduates, digital skills among the population, multi-stakeholder collaboration). The choice of these criteria is based on scientific literature and the authors' expertise.

The ranking of EU countries by the level of internationalization of knowledge transfer was done using TOPSIS method. Rank highlights Luxembourg, Sweden, Austria, Denmark and Finland as the TOP5 countries, and Poland, Croatia, Romania, Bulgaria and Greece as the last 5 countries in the rank. Authors suggest TOP5 countries from the ranking could provide a higher contribution in achieving SDGs, especially Goal 9 and Goal 17. Results also suggest countries with a higher interest in "global partnership". The results of this rank and GCI were compared and relevant similarities were found - countries ranked at the top of GCI also share high positions in the ranking of internationalization of knowledge transfer and vice versa.
This study contributes to existing theoretical knowledge in the knowledge management and knowledge transfer field, suggest a new approach to knowledge transfer analysis. Authors analyze knowledge transfer not by its role in the particular business sector but look at the subject from a broader perspective and analyze it at the international level, while linking knowledge transfer with a contribution to Sustainable Development Goals.

This study provides practical value and can be used as one of the tools for governments of European Union countries to forecast potential contribution to SDG level and run regular reviews of their performance, which are expected and recommended by the United Nations.

Research has its limitations that can be solved by involving external experts in a future research. External experts could potentially suggest additional, more precise criteria and provide deeper knowledge regarding the weights, given to selected criteria.

While this study analysed all EU countries, future research can focus on particular set of countries, in example Baltic region, Nordic region or South Europe, in more depth and follow their yearly performance, analyse and suggest ways to increase national or regional contribution to SDG.

\section{References}

Argote, L. (1999). Organizational learning: Creating, retaining, and transferring knowledge. Kluwer.

Bagheri, S., Kusters, R., \& Trienekens, J. J. M. (2015). Business-IT alignment in PSS value networks linking customer knowledge management to social customer relationship management (pp. 249-257). SciTePress. https://doi.org/10.5220/0005370002490257

Bagheri, S., Kusters, R. J., Trienekens, J. J. M., \& Zandt, H. V. N. (2016). Classification framework of knowledge transfer issues across value networks. Procedia CIRP, 47, 382-387. https://doi.org/10.1016/j.procir.2016.03.221

Chen, M., Huang, M., \& Cheng, Y. (2009). Measuring knowledge management performance using a competitive perspective: an empirical study. Expert Systems with Applications, 36(4), 8449-8459. https://doi.org/10.1016/j.eswa.2008.10.067

Frank, A. G., \& Duarte Ribeiro, J. L. (2014). An integrative model for knowledge transfer between new product development project teams. Knowledge Management Research \& Practice, 12(2), 215225. https://doi.org/10.1057/kmrp.2012.57

Fritz, S., See, L., Carlson, T., \& et al. (2019). Citizen science and the United Nations sustainable development goals. Nat Sustain, 2, 922-930. https://doi.org/10.1038/s41893-019-0390-3 
Galbraith, J. K. (1969). The New Industrial State. Princeton University Press.

Galli, A., Durovic, G., Hanscom, L., \& Knezevic, J. (2018). Think globally, act locally: Implementing the sustainable development goals in Montenegro. Environmental Science \& Policy, 84, 159-169. https://doi.org/10.1016/j.envsci.2018.03.012

Hanine, M., Boutkhoum, O., Tikniouine, A., \& Agouti, T. (2016). Application of an integrated multicriteria decision making AHP-TOPSIS methodology for ETL software selection. SpringerPlus, 5, 263. https://doi.org/10.1186/s40064-016-1888-z

Hogan, D. A., Stevens, G. A., Hosseinpoor, A. R., \& Boerma, T. (2018). Monitoring universal health coverage within the Sustainable Development Goals: development and baseline data for an index of essential health services. The Lancet Global Health, 6(2), 152-168. https://doi.org/10.1016/S2214-109X(17)30472-2

Hwang, C. L., \& Yoon, K. (1981). Multiple attribute decision making: methods and applications. Springer. https://doi.org/10.1007/978-3-642-48318-9

Joshi, K. D., Sarker, S., \& Sarker, S. (2007). Knowledge transfer within information systems development teams: examining the role of knowledge source attributes. Decision Support Systems, 43(2), 322335. https://doi.org/10.1016/j.dss.2006.10.003

Kumar, J., \& Ganesh, L. (2009). Research on knowledge transfer in organizations: a morphology. Journal of Knowledge Management, 13(4), 161-174. https://doi.org/10.1108/13673270910971905

Nobeoka, K. (1995). Inter-project learning in new product development. Academy of Management Journal, 38(4), 432-436. https://doi.org/10.5465/ambpp.1995.17536713

Noboeka, K., \& Cusumano, M. (1997). Multiproject strategy and sales growth: the benefits of rapid design transfer in new product development. Strategic Management Journal, 18(3), 169-186. https://doi.org/10.1002/(SICI)1097-0266 (199703)18:3<169::AID-SMJ863>3.0.CO;2-K

Nor Aziati, A. H., Juhana, S., \& Nor Hazana, A. (2014). Knowledge transfer conceptualization and scale development in IT outsourcing: the initial scale validation. Procedia - Social and Behavioral Sciences, 129, 11-22.

https://doi.org/10.1016/j.sbspro.2014.03.642

Patriotta, G., Castellano, A., \& Wright, M. (2013). Coordinating knowledge transfer: Global managers as higher-level intermediaries. Journal of World Business, 48(4), 515-526. https://doi.org/10.1016/j.jwb.2012.09.007

Peng, G., Dey, D., \& Lahiri, A. (2014). Healthcare IT adoption: an analysis of knowledge transfer in socioeconomic networks. Journal of Management Information Systems, 31(3), 7-34. https://doi.org/10.1080/07421222.2014.994672
Ragab, M. A. F., \& Arisha. A. (2013). Knowledge management and measurement: a critical review. Journal of Knowledge Management, 17(6), 873-901. https://doi.org/10.1108/JKM-12-2012-0381

Raudeliuniene, J., \& Szarucki, M. (2019). An integrated approach to assessing an organization's knowledge potential. Inzinerine Ekonomika - Engineering Economis, 30(1), 69-80. https://doi.org/10.5755/j01.ee.30.1.20807

Raudeliūnienè, J., Davidavičienè, V., \& Jakubavičius, A. (2018). Knowledge management process model. Entrepreneurship and Sustainability Issues, 5(3), 542-554. https://doi.org/10.9770/jesi.2018.5.3(10)

Sheng, M. L., Chang, S. Y., Teo, T., \& Lin, Y. F. (2013). Knowledge barriers, knowledge transfer, and innovation competitive advantage in healthcare settings. Management Decision, 51(3), 461-478. https://doi.org/10.1108/00251741311309607

Szulanski, G., Cappetta, R., \& Jensen, R. J. (2004). When and how trustworthiness matters: knowledge transfer and the moderating effect of causal ambiguity. Organization Science, 15(5), 499-616. https://doi.org/10.1287/orsc.1040.0096

Szulanski, G. (2003). Sticky knowledge: Barriers to knowing in the firm. Sage.

Tangaraja, G., Mohd Rasdi, R., Abu Samah, B., \& Ismail, M. (2016). Knowledge sharing is knowledge transfer: a misconception in the literature. Journal of Knowledge Management, 20(4), 653-670. https://doi.org/10.1108/JKM-11-2015-0427

United Nations. (2015). Transforming our world: the 2030 Agenda for Sustainable Development. https://sustainabledevelopment.un.org/post2015/tra nsformingourworld

Wong, K. Y., Tan, L. P., Lee, C. S., \& Wong, W. P. (2015). Knowledge Management performance measurement: measures, approaches, trends and future directions. Information Development, 31(3), 239-257. https://doi.org/10.1177/0266666913513278

World Economic Forum. (2012). The Global Competitiveness Report 2018.

https://www.weforum.org/reports/the-globalcompetitveness-report-2018

Xiao, W., Mills, J., Guide, G., \& et al. (2018). Geoinformatics for the conservation and promotion of cultural heritage in support of the UN Sustainable Development Goals. ISPRS Journal of Photogrammetry and Remote Sensing, 142, 389-406. https://doi.org/10.1016/j.isprsjprs.2018.01.001

Zimm, C., Sperling, F., \& Busch, S. (2018). Identifying sustainability and knowledge gaps in socioeconomic pathways Vis-à-Vis the sustainable development goals. Economies, 6(2). https://doi.org/10.3390/economies6020020 


\section{APPENDIX}

Appendix 1. Knowledge transfer phases and matching stages. Based on Frank and Duarte Ribeiro (2014)

\begin{tabular}{|c|c|}
\hline \multicolumn{2}{|c|}{ Phase 0: knowledge generation in the source } \\
\hline Stages & Authors and dates \\
\hline $\begin{array}{l}\text { Knowledge production; Individual's knowledge pro- } \\
\text { duction; Intra-project learning; Enlargement of an } \\
\text { individual's knowledge; Sharing tacit knowledge; } \\
\text { Storage }\end{array}$ & $\begin{array}{l}\text { Markus, 2001; Alavi and Leidner, 2001; Bartezzaghi } \\
\text { et al., 1997, Boer et al., 2001; Nonaka, 1994; Cartile and } \\
\text { Rebentish, } 2003\end{array}$ \\
\hline \multicolumn{2}{|c|}{ Phase 1: knowledge identification } \\
\hline Stages & Authors and dates \\
\hline $\begin{array}{l}\text { Awareness; Association; Acquisition; Capturing and } \\
\text { documenting; Storage; Abstraction; Acquiring; Initia- } \\
\text { tion; Retrieval; Generative variation }\end{array}$ & $\begin{array}{l}\text { Trott et al., 1995, Major and Cordey-Hayes, 2000, Li- } \\
\text { yanage et al., 2009; Marsh and Stock, 2003; Gilbert and } \\
\text { Cordey-Hayes, 1996; Markus, 2001; Alavi and Leidner, } \\
\text { 2001; Bartezzaghi et al., 1997; Boer et al., 2001; Szulan- } \\
\text { ski, 2000; Abou-Zeid, 2005; Carlile and Rebentisch, } \\
\text { 2003; Zollo and Winter, } 2002\end{array}$ \\
\hline \multicolumn{2}{|c|}{ Phase 2: knowledge processing } \\
\hline Stages & Authors and dates \\
\hline $\begin{array}{l}\text { Collection; Summarisation / Association; Translation } \\
\text { / Interpretation; Packaging knowledge; Acquisition; } \\
\text { Transformation; Association; Organisation and re- } \\
\text { trieval; Embodiment; Conceptualisation; Implementa- } \\
\text { tion; Transformation; Internal selection; Interrelation }\end{array}$ & $\begin{array}{l}\text { Major and Cordey-Hayes, 2000; Markus, 2001; Liyanage } \\
\text { et al., 2009; Alavi and Leidner, 2001; Bartezzaghi et al., } \\
\text { 1997; Nonaka, 1994; Szulanski, 2000; Carlile and Re- } \\
\text { bentisch, 2003; Zollo and Winter, 2002; Abou-Zeid, } \\
2005\end{array}$ \\
\hline \multicolumn{2}{|c|}{ Phase 3: knowledge dissemination } \\
\hline Stages & Authors and dates \\
\hline $\begin{array}{l}\text { Communication; Distribution; Distributing } \\
\text { knowledge; Transfer, transfering; Dissemination; } \\
\text { Replication }\end{array}$ & $\begin{array}{l}\text { Trott et al., 199; Gilbert and Cordey-Hayes, 1996; Marsh } \\
\text { and Stock, 2003; Markus, 2001; Alavi and Leidner, } \\
\text { 2001; Boer et al., 2001; Bartezzaghi et al., 1997; Zollo } \\
\text { and Winter, } 2002\end{array}$ \\
\hline \multicolumn{2}{|c|}{ Phase 4: knowledge applying in the recipient } \\
\hline Stages & Authors and dates \\
\hline $\begin{array}{l}\text { Assimilation; Interpretation; Retention; Application; } \\
\text { Commitment; Reusing knowledge; Crystallization } \\
\text { and justification; Networking knowledge; Ramp-up } \\
\text { (being using); Integration; Acceptance; Retention; } \\
\text { Implementation; Internalization }\end{array}$ & $\begin{array}{l}\text { Trott et al., 1995; Major and Cordey-Hayes, 2000; Marsh } \\
\text { and Stock, 2003; Liyanage et al., 2009, Alavi and } \\
\text { Leidner, 2001, Bartezzaghi et al., 1997, Gilbert and } \\
\text { Cordey-Hayes, 1996, Boer et al., 2001; Markus, 2001; } \\
\text { Nonaka, 1994; Szulanski, 2000; Gilbert and Cordey- } \\
\text { Hayes, 1996; Zollo and Winter, 2002; Abou-Zeid, } 2005\end{array}$ \\
\hline
\end{tabular}


Appendix 2. Knowledge management performance

\begin{tabular}{|c|c|}
\hline Measurement tools & Measurement techniques \\
\hline $\begin{array}{l}\text { Intangible Assets Monitor (Sveiby, 1997): measure } \\
\text { three categories of intangible assets such as individ- } \\
\text { ual competence, external structure and internal } \\
\text { structure. }\end{array}$ & \multirow{3}{*}{$\begin{array}{l}\text { Analytical Network Process or ANP (Saaty, 1996): is } \\
\text { a more general form of the Analytical Hierarchy Pro- } \\
\text { cess (AHP) which is a popular method for multi- } \\
\text { criteria decision making (MCDM). ANP allows the } \\
\text { ability to model more complex and dynamic environ- } \\
\text { ments that are more evident at strategic planning lev- } \\
\text { els. }\end{array}$} \\
\hline $\begin{array}{l}\text { Skandia Navigator (Edvinsson, 1997): evaluates soft } \\
\text { assets of organization and focuses on five areas - } \\
\text { financial, human aspect, renewal and development, } \\
\text { customer and process. }\end{array}$ & \\
\hline $\begin{array}{l}\text { Tobin's q Ratio (Tobin, 1998): defined as the capital } \\
\text { market value of a firm divided by the replacement } \\
\text { value of its assets. }\end{array}$ & \\
\hline $\begin{array}{l}\text { Human Resource Accounting (Flamholtz \& Main, } \\
\text { 1999): attempts to calculate the contribution that } \\
\text { human assets make to firms by capitalizing salary } \\
\text { expenditures. }\end{array}$ & \multirow{3}{*}{$\begin{array}{l}\text { Principal Component Analysis or PCA (Person, } \\
\text { 1901): examines the correlations between the evalua- } \\
\text { tion indicators, groups them into fewer indicators, and } \\
\text { makes these fewer indicators reflect the original tar- } \\
\text { get information. The result is a greatly simplified orig- } \\
\text { inal index structure of the indicators. }\end{array}$} \\
\hline $\begin{array}{l}\text { Balanced Scorecard (Kaplan \& Norton, 1992): } \\
\text { measures an organization based on four key areas: } \\
\text { financial, learning and growth, internal business } \\
\text { processes and customers. }\end{array}$ & \\
\hline $\begin{array}{l}K P^{3} \text { methodology assesses the contribution of each } \\
\text { knowledge entity to business performance through } \\
\text { product and process. }\end{array}$ & \\
\hline $\begin{array}{l}\text { Knowledge Management Performance Index (Lee } \\
\text { et al., 2005): it takes into account the dynamic nature } \\
\text { of knowledge and it possesses the ability to help } \\
\text { managers in making decisions on investment and } \\
\text { improvement of their KM processes. }\end{array}$ & $\begin{array}{l}\text { Fuzzy Logic (Zadeh, 1965): able to provide a simple } \\
\text { way to arrive at a definite conclusion based upon in- } \\
\text { complete or missing input information. }\end{array}$ \\
\hline $\begin{array}{l}\text { User-Satisfaction-Based System (Chin et al., 2010): } \\
\text { model is divided into two segments - knowledge } \\
\text { management enabler and knowledge management } \\
\text { result. The first focuses on measuring KM processes, } \\
\text { factors, and of course the knowledge users' orienta- } \\
\text { tion. As for the second, its purpose is to measure the } \\
\text { differences between what was planned and what was } \\
\text { carried out. }\end{array}$ & $\begin{array}{l}\text { Data Envelopment Analysis (DEA) (Kuah et al., } \\
\text { 2012): able to consolidate multiple performance } \\
\text { measures into an efficiency score, with minimum sub- } \\
\text { jective judgment from the evaluators. }\end{array}$ \\
\hline
\end{tabular}

Measurement tools and techniques. Based on Wong et al. (2015). 